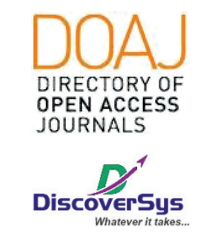

Published by DiscoverSys

\section{Kualitas hidup anak usia 12-15 tahun yang menderita tonsilitis kronis}

\author{
Sang Ayu Putu Novi Krisna Dewi KN,$^{1 *}$ Komang Andi Dwi Saputra, ${ }^{2}$ \\ Agus Rudi Asthuta, ${ }^{2}$ Sari Wulan Dwi Sutanegara ${ }^{2}$
}

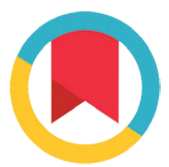

CrossMark

\title{
ABSTRACT
}

Background: Inflammation that occurs in palatine tonsils is often called tonsillitis. The incidence of tonsillitis in Indonesia around 23\% according to the Ministry of RI. In Bali, for oral health problems of $21.6 \%$ that occur in children aged 5-9 years and in children aged 10 14 years by $20.6 \%$ based on data from Riskesdas 2007.

Aim: This study aims to determine the quality of life of children aged 12 -15 years old suffering from chronic tonsillitis in SMP Negeri 1 Kintamani.

Methods: This descriptive study uses a cross sectional study design. This sample collection uses a descriptive conservative sample whose data is taken from a questionnaire taken at SMP Negeri 1 Kintamani with the conditions of inclusion and exclusion criteria.
Results: Samples obtained 20 samples, as many as 11 people (55\%) women were found to suffer the most from chronic tonsillitis, then the age group of 14 years 9 people (45\%). Based on the type of tonsils most patients have T2 tonsil type as many as 16 people (80\%). In terms of quality of life, almost all samples of 17 people (85\%) had a normal quality of life. Based on the type of quality of life of a total of 17 samples with normal quality of life as many as 15 people (88.24\%) had mild symptoms of tonsillitis while 2 people (11.76\%) the rest had symptoms of moderate and severe tonsillitis.

Conclusion: There was no significant difference was found in the proportion of tonsillitis symptoms in the sample group based on quality of life $(p=1.00)$ in SMP Negeri 1 Kintamani.

Keywords: tonsillitis, age, sex, diagnosis, and type of examination

Cite This Article: Dewi, K.N.S.A.P.N.K., Saputra, K.A.D., Asthuta, A.R., Sutanegara, S.W.D. 2020. Kualitas hidup anak usia 12-15 tahun yang menderita tonsilitis kronis. Intisari Sains Medis 11(2): 523-527. D0I: 10.15562/ism.v11i2.650

\section{ABSTRAK}

Inflamasi yang terjadi pada tonsil palatina sering disebut dengan tonsilitis. Kejadian tonsilitis di Indonesia sekitar 23\% berdasarkan Departemen RI. Di Bali, untuk masalah kesehatan mulut sebesar 21,6\% yang terjadi pada anak berusia 5-9 tahun dan pada anak usia 10-14 tahun sebesar 20,6\% berdasarkan data dari Riskesdas 2007. Tujuan: Penelitian ini bertujuan untuk mengetahui kualitas hidup anak usia 12-15 tahun yang menderita tonsilitis kronis di SMP Negeri 1 Kintamani.

PProgram Studi Sarjana Kedokteran dan Profesi Dokter, Fakultas Kedokteran, Universitas Udayana, Denpasar, Bali ${ }^{2}$ Departemen/KSM IImu Kesehatan THT-KL Fakultas Kedokteran, Universitas Udayana, Denpasar, Bali

${ }^{*}$ Correspondence to:

Sang Ayu Putu Novi Krisna Dewi KN, Program Studi Sarjana Kedokteran dan Profesi Dokter, Fakultas Kedokteran, Universitas Udayana, Denpasar, Bali krisnadewi2896@gmail.com

Diterima: 23-10-2019

Disetujui: 09-07-2020

Diterbitkan: 01-08-2020

Kata Kunci: Tonsilitis, usia, jenis kelamin, diagnosis, dan jenis pemeriksaan tonsilitis kronis. Intisari Sains Medis 11(2): 523-527. D0I: 10.15562/ism.v11i2.650

\section{PENDAHULUAN}

Peradangan yang terjadi pada tonsil palatina sering disebut sebagai tonsilitis dimana tonsil palatina ini merupakan kumpulan dari beberapa tonsil yang membentuk cincin yang disebut sebagai cincin Waldeyer. ${ }^{1}$ Peradangan
Hasil: Sampel yang didapatkan 20 sampel, sebanyak 11 orang (55\%) perempuan ditemukan paling banyak menderita tonsilitis kronis, kemudian kelompok usia 14 tahun 9 orang (45\%). Berdasarkan tipe tonsilnya paling banyak pasien memiliki tipe tonsil T2 sebanyak 16 orang (80\%). Ditinjau dari kualitas hidupnya hampir seluruh sampel sebanyak 17 orang (85\%) memiliki kualitas hidup yang normal. Berdasarkan jenis kualitas hidupnya dari total 17 orang sampel dengan kualitas hidup normal sebanyak 15 orang $(88,24 \%)$ memiliki gejala tonsilitis yang ringan sementara 2 orang $(11,76 \%)$ sisanya memiliki gejala tonsilitis yang sedang dan berat.

Kesimpulan: Perbedaan bermakna tidak ditemukan dari proporsi gejala tonsilitis pada kelompok sampel berdasarkan kualitas hidupnya $(p=1,00)$ di SMP Negeri 1 Kintamani.

Cite Pasal Ini: Dewi, K.N.S.A.P.N.K., Saputra, K.A.D., Asthuta, A.R., Sutanegara, S.W.D. 2020. Kualitas hidup anak usia $12-15$ tahun yang menderita

pada tonsil dapat menyebabkan pembesaran yang mengakibatkan kesulitan saat menelan. ${ }^{2}$ Pada anak-anak biasanya keadaan seperti ini akan menyebabkan ngorok saat tidur akibat pengaruh dari besarnya tonsil yang mengganggu 
pernapasan dan juga dapat terjadi penutupan jalur pernapasan. ${ }^{3}$

Di Amerika Serikat, diperkirakan prevalensi tonsilitis kronis sebesar 1,59\%. ${ }^{4}$ Tercatat $11,7 \%$ anak-anak mengalami tonsilitis di Norwegia sedangkan di Turki tercatat anak-anak yang mengalami tonsilitis sebesar $12 \%{ }^{5}$ Didapatkan 35 penderita tonsilitis kronis oleh penelitian Nurjannah tahun 2011 yang memiliki keluhan sakit menelan terbanyak 24 penderita. Usia 11-20 tahun merupakan usia terbanyak ditemukannya tonsilitis kronis yaitu 70 (47\%) penderita. ${ }^{6}$ Peristiwa tonsilitis kronis terjadi setengah dari total kejadian yang menunjukkan usia anak di bawah 18 tahun dengan rentang usia 10-14 tahun di RSUP Dr. M. Djamil Padang. ${ }^{7}$

Tonsilitis kronis dapat diakibatkan banyak faktor, yang sering yaitu infeksi bakteri Streptococcus dikarenakan kekambuhan berulang dari tonsilitis akut yang menyebabkan rusaknya tonsil secara menetap, selain itu dapat juga terjadi karena adanya fase revolusi yang tidak adekuat. ${ }^{8}$ Anak-anak usia sekolah yang gemar memakan-makanan yang memiliki kandungan bahan pengawet, pewarna buatan, pemanis buatan, dan minum-minuman yang dingin bisa memicu peradangan pada tenggorok atau infeksi pada tonsil. ${ }^{2}$ Faktor lain yang menyebabkan timbulnya tonsilitis kronis adalah rangsangan menahun dari rokok, cuaca, keadaan fisik yang lemah, kebersihan mulut, dan pengobatan tonsilitis akut yang tidak diselesaikan dengan tuntas. ${ }^{9}$

Keluhan utama yang dirasakan pada penderita tonsilitis kronis bervariasi dari gejala lokal, gejala sistemis, dan gejala klinis. Gejala lokal yang ditimbulkan meliputi tidak enak di tenggorok diakibatkan tonsil yang membesar, susah menelan, dan nyeri. Gejala sistemik berupa tidak enak badan, kepala terasa nyeri, demam, otot terasa nyeri, dan nyeri persendian. Gejala klinis berupa kripte membesar dan melebar, hiperemis pada plika tonsilaris anterior, kelenjar limfe regional yang membesar dan meradang, dan pembesaran tonsil yang dapat menimbulkan OSA (obstructive sleep apnea) dengan gejala ngorok atau mendengkur saat tidur. ${ }^{6}$

Tonsilitis kronis memiliki dampak besar terhadap kualitas hidup yang mana dapat dikaitkan dengan kemampuan aktifitas fisik seseorang dalam kehidupan sehari-hari dalam hal ini penurunan prestasi belajar pada anak..$^{10}$ Kejadian tonsilitis di Indonesia sebanyak 23\% yang di data oleh Departemen Kesehatan RI. ${ }^{4}$ Berdasarkan data Riskesdas 2007, Bali memiliki masalah kesehatan mulut sebanyak $21,6 \%$ pada anak rentang usia 5-9 tahun, sedangkan pada anak dengan rentang usia 10-14 tahun ditemukan sebanyak 20,6\%." Pada Kabupaten Bangli, belum ada bukti mengenai profil pasien yang terkena masalah gigi dan mulut khususnya tonsilitis kronis pada anak-anak. Berdasarkan uraian tersebut peneliti melakukan penelitian tentang kualitas hidup anak usia 12-15 tahun yang menderita tonsilitis kronis di SMP Negeri 1 Kintamani.

\section{METODE}

Ini merupakan jenis penelitian deskriptif cross sectional (potong lintang) guna menilai kualitas hidup pasien tonsilitis kronis. Pengumpulan sampel penelitian ini dilakukan bersamaan pada satu waktu menggunakan kuesioner. Seluruh anak yang menderita tonsilitis kronis di SMP Negeri 1 Kintamani tercatat menjadu populasi target. Populasi terujangkau yaitu anak usia 12-15 tahun yang menderita tonsilitis kronis di SMP Negeri 1 Kintamani. Sampel pada penelitian ini diambil dari kuesioner semua anak usia 12-15 tahun yang terdiagnosis tonsilitis kronis di SMP Negeri 1 Kintamani. Teknik pengumpulan sampel yang digunakan adalah deskriptif conservative sampling atau rumus hitung minimal yang termasuk dalam kriteria inklusi dan kriteria eksklusi. Anak usia 12-15 tahun yang terdiagnosis tonsilitis kronis di SMP Negeri 1 Kintamani yang terpilih menjadi subjek penelitian, sukarela, dan mau menandatangani surat pernyataan persetujuan merupakan kriteria inklusi. Anak usia 12-15 tahun yang terdiagnosis tonsilitis kronis yang terpilih menjadi subjek penelitian, tetapi tidak mau menandatangani surat pernyataan persetujuan menderita penyakit berat dan mundur pada saat proses penelitian secara sukarela merupakan kriteria eksklusi.

Instrumen yang dipakai berupa kuesioner responden yang dilakukan di SMP Negeri 1 Kintamani. Analisis data yang digunakan laptop portabel. Penelitian ini menggunakan data primer. Data-data mencakup umur atau usia, jenis kelamin atau gender, ukuran pembesaran tonsil, skoring gejala tonsilitis, kualitas hidup. Data pertama akan dimasukkan kedalam laptop, kemudian dilakukan penyuntingan untuk memilah variable yang belum diberi kode. Setelah pemberian kode dan disunting, data akan diolah menggunakan aplikasi SPSS v.17 ke dalam format yang telah dibuat dan dilakukan pembersihan data. Data yang terkumpul akan diolah dengan tujuan mengetahui kualitas hidup anak usia 12-15 tahun yang menderita tonsilitis kronis. Penyajian data-data tersebut dapat berupa tabel. Penelitian telah mendapat izin dari Komisi Etik Penelitian (KEP) Fakultas Kedokteran 
Universitas Udayana dengan nomor surat 2703/ UN14.2.2.VII.14/LP/2019

\section{HASIL}

Hasil penelitian menunjukkan dari keseluruan 20 sampel bahwa sampel yang terkumpul dengan rentang usia 13 - 15 tahun. Dari keseluruhan sampel 8 orang $(40,0 \%)$ berusia 13 tahun, sebanyak 9 orang $(45,0 \%)$ berusia 14 tahun, dan sebanyak 3 orang $(15,0 \%)$ berusia 15 tahun. Pasien dengan jenis kelamin perempuan mendominasi jumlah sampel yaitu sebanyak 11 orang $(55,0 \%)$, jika dibandingkan dengan pasien jenis kelamin laki laki yaitu sebanyak 9 orang $(45,0 \%)$. Berdasarkan tipe tonsilnya sebagian besar pasien memiliki tipe tonsil T2 yaitu sebanyak 16 orang (80,0\%), sementara sisanya adalah tipe tonsil T3 yaitu sebanyak 2 orang (10,0\%), dan tipe tonsil T4 yaitu sebanyak 2 orang (10,0\%). Dari total keseluruhan sampel lebih dari setengah (70,0\%) sampel memiliki gejala tonsilitis ringan dan sedang, sementara sisanya $(30,0 \%)$ memiliki gejala tonsilitis berat. Apabila ditinjau dari kualitas hidupnya, hampir seluruh sampel yaitu sebanyak 17 orang (85,0\%) mempunyai kualitas hidup yang normal, sementara sebanyak 3 orang $(15,0 \%)$ sisanya memiliki kualitas hidup yang berisiko.

Hasil penelitian menunjukkan, berdasarkan gejala tonsilitisnya, dari total 6 orang sampel

\section{Tabel 1 Karakteristik demografi sampel penelitian}

\begin{tabular}{|c|c|c|}
\hline Variabel & Frekuensi (N) & Proporsi (\%) \\
\hline \multicolumn{3}{|l|}{ Usia } \\
\hline 13 Tahun & 8 & 40,0 \\
\hline 14 Tahun & 9 & 45,0 \\
\hline 15 Tahun & 3 & 15,0 \\
\hline \multicolumn{3}{|l|}{ Jenis Kelamin } \\
\hline Laki-Laki & 9 & 45,0 \\
\hline Perempuan & 11 & 55,0 \\
\hline \multicolumn{3}{|l|}{ Tipe Tonsil } \\
\hline $\mathrm{T} 1$ & 0 & 0,0 \\
\hline $\mathrm{T} 2$ & 16 & 80,0 \\
\hline $\mathrm{T} 3$ & 2 & 10,0 \\
\hline $\mathrm{T} 4$ & 2 & 10,0 \\
\hline \multicolumn{3}{|c|}{ Skoring Gejala Tonsilitis } \\
\hline Berat $(\geq 6)$ & 6 & 30,0 \\
\hline $\begin{array}{l}\text { Ringan dan } \\
\text { Sedang }(\leq 5)\end{array}$ & 14 & 70,0 \\
\hline \multicolumn{3}{|l|}{ Kualitas Hidup } \\
\hline Normal & 17 & 85,0 \\
\hline Berisiko & 3 & 15,0 \\
\hline
\end{tabular}

Tabel 2 Analisis variabel skoring gejala tonsilitis terhadap variabel kualitas hidup

\begin{tabular}{|c|c|c|c|c|}
\hline \multirow[b]{2}{*}{ Variabel Skoring Gejala Tonsilitis } & \multicolumn{2}{|c|}{ Kualitas Hidup [N (\%)] } & \multirow[b]{2}{*}{ Total N (\%) } & \multirow[b]{2}{*}{$p$} \\
\hline & Berisiko & Normal & & \\
\hline Berat & $1(16,7 \%)$ & $5(83,3 \%)$ & $6(100 \%)$ & \multirow{2}{*}{1,00} \\
\hline Ringan dan Sedang & $2(14,3 \%)$ & $12(85,7 \%)$ & $14(100 \%)$ & \\
\hline
\end{tabular}

Tabel 3 Analisis variabel jenis kelamin terhadap variabel kualitas hidup

\begin{tabular}{|c|c|c|c|c|}
\hline \multirow[b]{2}{*}{ Variabel Jenis Kelamin } & \multicolumn{2}{|c|}{ Kualitas Hidup [N (\%)] } & \multirow[b]{2}{*}{ Total N (\%) } & \multirow[b]{2}{*}{$p$} \\
\hline & Berisiko & Normal & & \\
\hline Laki-Laki & $0(0,0 \%)$ & $9(100,0 \%)$ & $9(100 \%)$ & \multirow{2}{*}{0.22} \\
\hline Perempuan & $3(27,3 \%)$ & $8(72,7 \%)$ & $11(100 \%)$ & \\
\hline
\end{tabular}


dengan gejala tonsilitis berat, hampir seluruhnya yaitu 5 orang $(83,3 \%)$ memiliki kualitas hidup normal, sementara 1 orang $(16,7 \%)$ memiliki kualitas hidup berisiko. Selanjutnya dari dari total 14 orang sampel dengan gejala tonsilitis ringan dan sedang, sebanyak lebih dari setengahnya yaitu 12 orang $(85,7 \%)$ memiliki kualitas hidup normal, sedangka sisa 2 orang lainnya (14,3\%) memiliki kualitas hidup berisiko. Beerdasarkan uji Chi-Square Fisher's Exact tidak terdapat perbedaan yang bermakna dari proporsi gejala tonsilitis pada kelompok sampe berdasarkan kualitas hidupnya $(p=1,00)$ dengan $95 \%$ interval kepercayaan sebesar 0,129-10,547 yang berarti tidak ada hubungan antara skoring gejala tonsilitis dengan kualitas hidup, dengan nilai RP 1,16 berarti orang dengan skor gejala tonsilitis berat berisiko 1,16 kali untuk mengalami penurunan kualitas hidup.

Hasil penelitian apabila ditinjau dari segi jenis kelamin pada kelompok sampel berdasarkan kualitas hidupnya (Tabel 3). Dari total 9 orang (100\%) orang dengan jenis kelamin laki - laki, secara keseluruhan (100\%) memiliki kualitas hidup yang normal, sementara dari seluruh sampel dengan jenis kelamin perempuan hampir seluruhnya yaitu 8 orang $(72,7 \%)$ memiliki kualitas hidup normal sementara sisanya yaitu 3 orang $(27,3 \%)$ mempunyai kualitas hidup yang berisiko. Uji chi-square Fisher's exact menunjukkan bahwa perbedaan yang bermakna tidak ditemukan dari proporsi jenis kelamin pada kelompok sampel berdasarkan kualitas hidupnya $(p=0,22)$.

\section{DISKUSI}

Hasil penelitian menunjukkan karakteristik demografi sampel penelitian yang terkumpul sebanyak 20 sampel dengan rentang usia 13-15 tahun. Penelitian sebelumnya yang dilakukan di RSUP Dr. M. Djamil Padang yang menunjukkan bahwa setengah dari total kejadian tonsilitis kronis yang terjadi pada anak usia di bawah 18 tahun berada pada kelompok usia 10-14 tahun, jadi dari penelitian sebelumnya dan sekarang sesuai tidak ditemukan adanya perbedaan. Menurut teori, menurunnya fungsi tonsil pada usia mencapai 15 tahun oleh karena involusi saat pubertas menyebabkan sistem kekebalan tubuh menurun sehingga membuat anak lebih rentan terhadap infeksi. ${ }^{7}$ Terlebih lagi sebagian besar waktu anak yang dihabiskan di luar ruangan dan kebiasaan mengonsumsi makanan ringan dengan kadar bahan pengawet yang tinggi dapat meningkatkan risiko terjadinya iritasi bahkan infeksi pada saluran pernapasan atas dan tenggorok. ${ }^{12}$

Terkait karakteristik jenis kelamin, perempuan lebih berisiko mengalami tonsilitis kronis dibandingkan laki-laki. Hasil ini sebanding dengan dua penelitian sebelumnya di RSUP Dr. M. Djamil Padang dan di Puskesmas Minasatene, Pangkep yang menemukan bahwa lebih banyak anak perempuan yang menderita tonsilitis kronis dibandingkan anak laki-laki. Pola ini dapat dijelaskan oleh karena kebutuhan nutrisi yang meningkat pada masa pubertas. Pada masa akil balik ini, anak perempuan sering mempunyai frekuensi makan yang lebih rendah dibandingkan anak laki-laki, sehingga kebutuhan kalori dan protein yang meningkat tidak terpenuhi dengan baik. Daya tahan tubuh anak perempuan juga ditemukan tidak sama tingginya dibandingkan dengan anak laki-laki dikarenakan sensitifitas yang lebih tinggi terhadap infeksi dan rangsangan nyeri, meskipun begitu kemaknaan jenis kelamin pada kejadian tonsilitis kronis dan rekuren sampai saat ini belum dapat dibuktikan. ${ }^{6}$

Sebagian besar sampel pada penelitian ini memiliki tipe tonsil T2 yaitu sebanyak $80 \%$. Hal ini serupa dengan penelitian potong lintang sebelumnya oleh Farokah dan penelitian yang dilakukan di Denizli Turkey yang menemukan angka tipe tonsil T1-T2 yang lebih tinggi dibandingkan tipe tonsil T3 atau T4 dengan angka $57,2 \%$ dan $62 \%$ berturut-turut. ${ }^{13-14} \mathrm{Hal}$ ini berbeda dengan studi yang dilakukan di RSUP Dr. M. Djamil Padang yang menemukan sebagian besar sampelnya memiliki tipe tonsil T3 (68\%). Hiperplasia parenkim atau degenerasi fibrinoid dengan ditambah adanya obstruksi kripta tonsil dapat menyebabkan ukuran tonsil akan membesar. Infeksi yang terjadi secara berulang akan mengakibatkan penurunan dari fungsi epitel kripta sehingga bakteri mudah masuk ke parenkim tonsil. Bakteri ini dapat berlipat ganda kemudian menetap di dalam kripta tonsil, sehingga mengakibatkan infeksi tonsil yang berulang. Perbedaan proporsi tipe tonsil pada masingmasing penelitian masih belum dapat dijelaskan, namun hal ini dapat diduga oleh karena pengaruh genetik dalam suatu populasi dan daya tahan tubuh individual dalam menangani infeksi. ${ }^{15}$

Sebagian besar dari sampel mengalami gejala tonsilitis ringan dan sedang (70\%). Penelitian yang dilakukan oleh Shalihat, Novialdi, dan Irawati yang dilakukan di RSUP DR. M. Djamil Padang pada tahun 2013 menunjukkan bahwa sebagian besar orang yang mengalami tonsilitis kronis menunjukkan keluhan utama berupa rasa nyeri atau sakit saat menelan $(72,5 \%)$, rasa mengganjal di tenggorok $(10,7 \%)$ serta gejala lainnya. Hal ini menunjukkan bahwa pasien dengan tonsilitis kronis meski sebagian besar mengeluhkan masalah tenggorok dapat datang dengan berbagai macam keluhan lainnya yang dapat berpengaruh pada poin skoring tonsilitis kronis. 
Berdasarkan hasil yang sudah dipaparkan diatas pada Tabel 2. mengenai gejala tonsilitis yang dialami, pada penelitian ini ditemukan bahwa derajat gejala tonsilitis kronis tidak ada kaitannya dengan kualitas hidup pasien. Hasil ini tidak sesuai dengan penelitian sebelumnya di RSUD dr. Zainoel Abidin Banda Aceh yang menemukan bahwa derajat tonsilitis kronik berhubungan bermakna dengan kualitas hidup pasien, dimana semakin berat gejala yang dialami pasien maka semakin buruk kualitas hidupnya $(\mathrm{p}=0,007)$. Perbedaan ini dapat dijelaskan oleh karena kurangnya jumlah sampel yang terlibat dalam penelitian ini, selain itu tempat pengambilan sampel juga berpengaruh. Pada penelitian sebelumnya tempat pengambilan sampel dilakukan di rumah sakit kepada orang sakit, sedangkan pada penelitian ini dilakukan di baksos (bakti sosial). Bertambahnya jumlah sampel tentunya akan dapat lebih menunjukkan pola data yang lebih jelas.

Berdasarkan hasil yang dipaparkan pada Tabel 3. Mengenai jenis kelamin yang tidak memiliki asosiasi dengan kualitas hidup pasien tonsilitis kronis. Hal ini dapat terjadi pula karena minimnya jumlah sampel. Selain itu jika kembali meninjau karakteristik demografi, maka terlihat distribusi pasien dengan kualitas hidup normal (85\%) dan berisiko (15\%) sangat berbeda sehingga pola distribusi data yang sebenarnya masil belum bisa dicapai.

\section{SIMPULAN}

Anak yang mengalami tonsilitis kronis di SMP Negeri 1 Kintamani paling banyak terjadi pada anak usia 14 tahun. Anak yang mengalami tonsilitis kronis lebih banyak terjadi pada perempuan. Anak yang mengalami tonsilitis kronis di SMP Negeri 1 Kintamani tercatat paling banyak memiliki tipe tonsil T2. Anak yang mengalami tonsilitis kronis di SMP Negeri 1 Kintamani memiliki kualiatas hidup hampir seluruh sampel normal.

\section{UCAPAN TERIMAKASIH}

Tidak lupa juga peneliti mengucapakan terimakasih kepada Kristian Dwi Cahya, rekan sejawat di bagian THT-KL yang selalu siaga dalam diminta bantuan serta seluruh rekan-rekan lainnya yang tidak bisa saya sebutkan satu-persatu.

\section{DAFTAR PUSTAKA}

1. Sembiring R O, Porotu'o, J, Waworuntu O. Identifikasi Bakteri dan Uji Kepekaan Terhadap Antibiotik pada Penderita Tosilitis di Poliklinik THT KL BLU RSU. Prof. Dr. R. D. Kandou Manado Periode November 2012 Januari-2013. Jurnal e-Biomedik. 2013;1(2), 1053-1057.

2. Fachir F, S, Qamariah N, Marisa D. Hubungan Tonsilitis Kronis dan Otitis Media Efusi di Bagian THT RSUP Ulin Banjarmasin Tahun 2014. Berkala Kedokteran. 2014;12(1), 27-32.

3. Fakh I M, Novialdi, Elmatris. Karakteristik Pasien Tonsilitis Kronis pada Anak di Bagian THT-KL RSUP Dr. M. Djamil Padang Tahun 2013. Jurnal Kesehatan Andalas. 2016;5(2).

4. Ramadhan F, Sahrudin, Ibrahim K. Analisis Faktor Risiko Kejadian Tonsilitis Kronis Pada Anak Usia 5-11 Tahun di Wilayah Kerja Puskesmas Puuwatu Kota Kendari Tahun 2017. Jurnal Ilmiah Mahasiswa Kesehatan Masyarakat. 2017;2(6).

5. Sakka I, Sedjawidada R, Kodrat L, Rahardjo S P. Kadar Imunoglobulin A Sekretori pada Penderita Tonsilitis Kronik Sebelum dan Setelah Tonsilektomi. Orli. 2011;41(1).

6. Shalihat A O, Novialdi, Irawati L. Hubungan Umur, Jenis Kelamin dan Perlakuan Penatalaksanaan dengan Ukuran Tonsil pada Penderita Tonsilitis Kronis di Bagian THT-KL RSUP DR. M. Djamil Padang Tahun 2013. Jurnal Kesehatan Andalas. 2013;4(3).

7. Shirley W P, Wolley A L, Wiatrak BJ. Pharyngitis and adenotonsillar disease. Dalam: Cummings. Otolaryngology Head \& Neck Surgery. Philadelphia: Mosby Elsevier; 2010:2784-5.

8. Palandeng A C, Tumbel R E C, Dehoop J. Penderita Tonsilitis di Poliklinik THT-KL Blu RSUP Prof. DR. R. D. Kandou Manado Januari 2010-Desember 2012. Jurnal e-Clinic. 2014;2(2).

9. Koagouw G A, Mengko S K, Sondakh A R. Kesehatan Tenggorok Siswa SMA Negeri 9 Manado. Jurnal e-Clinic. 2016;4(1).

10. Triastuti N J, Rahman F, Akbar M A, Dasuki M S, Sintowati R. Pengaruh Status Gizi dan Tonsilitis Kronik Terhadap Prestasi Belajar pada Siswa Sekolah Dasar. Biomedika. 2015;7 (1).

11. Suarjaya K. Profil Kesehatan Provinsi Bali Tahun 2012. Kepala Dinas Kesehatan Provinsi Bali; 2013: p. 52.

12. Alfarisi R, Damayanti S, Tan'im. Hubungan Kebiasaan Makan dengan Risiko Terjadinya Tonsilitis Kronik pada Anak Sekolah Dasar di Bandar Lampung. Malahayati Nursing Journal. 2019;1(2):187-195.

13. Akcay A, Kara CO, Dagdefiren E, Zencir M. Variation in tonsil size in 4 to 17 years old schoolchildren. The Journal of Otolaryngology. 2006;35(4):270-4.

14. Amalia N. Karakteristik penderita tonsilitis kronis di RSUP H. Adam Malik Medan tahun 2009 (skripsi). Medan: Fakultas Kedokteran Universitas Sumatera Utara; 2011.

15. Novialdi N, Pulungan MR. Mikrobiologi Tonsilitis Kronis. Padang: Universitas Andalas; 2015.

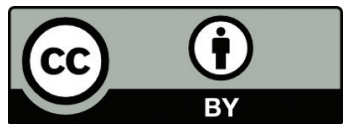

This work is licensed under a Creative Commons Attribution 